\title{
MACROECONOMIC VARIABLES AND NIGERIAN AGRICULTURAL SECTOR DEVELOPMENT
}

\section{Prof. Okafor Onwuagana ${ }^{1}$ and Dr. Isibor Areghan ${ }^{2}$}

${ }^{1}$ Baze University, Nigeria

${ }^{2}$ Covenant University, Nigeria

\section{Cite this article:}

Okafor O., Isibor A. (2021),

Macroeconomic Variables and Nigerian Agricultural Sector Development. British Journal of Management and

Marketing Studies 4(4), 9-20. DOI: 10.52589/BJMMS-

TTLY6KLR.

\section{Manuscript History}

Received: 15 Sept 2021

Accepted: 9 Oct 2021

Published: 19 Oct 2021

Copyright $\odot 2020$ The Author(s). This is an Open Access article distributed under the terms of Creative Commons AttributionNonCommercial-NoDerivatives 4.0 International (CC BY-NC-ND 4.0 ), which permits anyone to share, use, reproduce and redistribute in any medium, provided the original author and source are credited.
ABSTRACT: The study investigated the impact of some macroeconomic variables like exchange rate and inflation on the development of the Nigerian agricultural industry. Annual time series secondary data covering a period of 33 years (1986-2020) was utilized in the study while the Ordinary Least Square (OLS) was the estimation technique used to analyze the data. Findings revealed that the exchange rate was positively significant in impacting the dependent variable while the inflation rate was negatively significant. The interest rate was insignificant in impacting the agricultural sector. From the findings, one recommendation arrived at was that the monetary authorities should make policies that would reduce inflation, for example, reduction of the money supply. Reduced inflation would positively impact the development of the agricultural sector as it would boost and increase the consumption of agricultural products.

KEYWORDS: Agricultural Sector, Agricultural Output, Exchange Rate, Inflation, Interest rate 


\section{INTRODUCTION}

Agricultural development is essentially the provision of food, raw materials for manufacturing, investment and generates government revenue so as to maintain the growth of other sectors of the economy, to receive an additional international exchange, and provide local producers with a rising marketplace. Nigerians are gifted with lands, streams, rivers, grassland, forest, and lakes, and most prominently a large vigorous population that can produce an industrious and productive agricultural sector. Even with all these endowments the agricultural sector endlessly delivered below potentials. Agriculture hires almost three-quarters of the workforce of Nigeria, as in the instance of sub-Saharan Africa (SSA) (Inam \& Oscar, 2017).

Agricultural output assessment of Nigeria showed the weakening production growth from the 1960s to 1980s. Nigeria had robust financial progress in the past few years, an average of $8.8 \%$ from 2000 to 2007 of its real annual GDP growth. While the farming industry has fallen behind GDP growth, it grew by 3.7\% in 2007 (Inam \& Oscar, 2017). From independence to the beginning of the 1960s, the economy has been categorized through the dominance of the export of commonly agricultural produce and other profitable activities. Despite the variation in world product prices, agriculture funded approximately $65 \%$ of the GDP and embodied nearly $70 \%$ of the overall exports. The foreign exchange that was provided by agriculture employed in the import of raw and capital products as the small farmer created sufficient food to go round the whole country, the numerous Promotion Boards spawned ample revenue, of which the extra was utilized by the government to advance fundamental structures required for lengthy-time enlargement (Udah, Nwachukwu, Nwosu, Mbanasor, \& Akpan, 2015).

Since Nigeria's oil industry grew in the late sixties, the agricultural sector has been entirely abandoned. The role of agriculture has remained on the sliding trend, particularly its influence on GDP, and its shares from 48,23\% in 1971 to almost $21 \%$ in 1977, GDP collapsed. (Ayanwu, 1997). Mordi (2006) reported that the addition of the agricultural sector to GDP advancement in 2003 raised by only 6.9 per cent. The sector grew by an average of 7.2 per cent from the year 2005 to 2007. Between 2008 and 2011, the agricultural sector's growth started to fail. It rose by $6.3 \%, 5.9 \%, 5.8 \%$, and $5.7 \%$ respectively in the years 2008,2009 , 2010 and 2011 correspondingly. In the year 2012, the advancement in the farming segment weakened to $3.9 \%$. Also in the year 2013, agricultural creation raised to $4.5 \%$, encouraging conditions of weather and non-stop applications of agricultural creativities are mainly accountable for the development of the sector (CBN 2018).

One of Nigeria's most intense events in recent years has been the depreciation of Nigerian Naira with the acceptance of a Structural Adjustment Program (SAP). SAP's main aim is to reform the economy's output foundation with a strong bias for agricultural export production. The foreign exchange restructurings which eased an accumulative devaluation of the active exchange rate were likely to raise the home prices of agricultural export and therefore increase domestic production (CBN, 2018). In Nigeria, there is the current source of the foreign exchange market. Indeed, in 1962, there was no true exchange market in the country. The Nigerian pound, connected to a long tie with the colonial masters of the past, was secured by Britain, which was easily converted to the British pound sterling. The situation added mainly to the late progress of vigorous Nigeria's foreign exchange market. Throughout the era, Private-sector foreign exchange (mostly from agricultural production) was alleged by commercial banks represented as agents for indigenous agricultural exporters in balances in foreign countries. The effect on the establishment of the Nigerian Central Bank (CBN) in 
1958, and the succeeding concentration of the foreign exchange market turn out to be overbearing. There is vigorous connection amid exchange rate and agriculture variation in the exchange rate market will lead to a decrease in agricultural production and also, it will affect exporting of agricultural produce. Notwithstanding the acceptance of the programs at numerous phases to sustain steady exchange rates which attested unsuccessful, exchange rate varies extensively particularly after the emergence of the Structural Adjustment Programme (SAP). And so, the sliding trend on the legal tender impacted significantly on the export of agricultural products.

During the fixed currency period, it was assumed that the Nigerian currency was overstated with the purpose of finding a more precise value of Naira; the Structural Adjustment Program of the Second-Tier External Exchange Market (SFEM) started in September 1986 and marked the beginning of flexible or flexible currency regimes. Many related market-based exchange policies and different sliding currencies were encountered; the well-known two-pronged exchange rate system, which was \$2,0206/Naira in September 1986; Dutch auction system (DAS) of bidding was decreased by $\$ 4,0279$ in April 1987; Dutch foreign exchange management retail auction system (RDAS) in July 2002; Naira decreased by $\$ 130,8500$; the wholesale Dutch Auction System (WDAS) decreased by February 2006 to $\$ 141,7600$, and date to RDAS by October 2012 (Odion, 2013).

Despite the acceptance of these policies at many stages to safeguard a rapid and ineffective exchange rate, the exchange rates vary widely especially after the Structural Adjustment Program (SAP) was founded. Consequently, Nigeria's currency depreciation has severely affected agricultural products.

It has made it problematic for the agricultural sector to grow because of exchange-rate variation from time to time. Because of the awful exchange rate, agricultural output is not effectively distributed. Fluctuation in exchange rates dissuades firms from investing, innovating and trading, may also dissuade firms from accessing the agricultural markets and thus flag the confidence of investors in the sector. The exchange rate for the agricultural sector also raises price increases of imported inputs like seeds, fertilizer, pesticides and agricultural equipment and thus reduces agricultural commodities, farmers' returns and exchange rate risk which contributes to the turnaround of capital deemed to be disapproval for the economy during difficult times.

\section{Link between Exchange Rate and Agricultural Output}

This link was explained by Sial \& Carter (1996) who explained that:

(i) There are three sectors: the booming (B) sector that in Nigeria, is comparable to the gas and oil sector, the lagging (L) sector that in Nigeria, is comparable to the agricultural sector, and the non-tradable $(\mathrm{N})$ sector which equates to Nigerian services;

(ii) the first two (B and L) sectors manufacture products exchanged at global prices;

(iii) the quantity manufactured by a sector-wide and labour variable that is mobile amongst all three sectors and between sectors, in order to align wages, are manufactured in each sector; 
(iv) All prices of factors are elastic and all variables are still international. In view of the underlying assumptions, this model has two separate effects, namely the effect of expenditure and the effect of movement of resources resulting from a B boom. The initial impact of this boom is to raise total revenues from the variables initially used in it and L. The mobilization of resources effects: Furthermore, as a consequence of the boom, the marginal work product rises in $\mathrm{B}$, so that the labour supply in B is rising at a steady wage for trade goods, and this compels a labour movement out of $\mathrm{L}$ and out of $\mathrm{N}$. There are two aspects to this effect:

(a) Labor movement from $\mathrm{L}$ to $\mathrm{B}$ infuriates output from $\mathrm{L}$. Direct deindustrialization could be referred to because it doesn't include the $\mathrm{N}$ market and thus does not need the real rate of exchange to appreciate.

(b) Work moves from $\mathrm{N}$ to $\mathrm{B}$ at a constant real exchange rate. Concerning the spending effect, the supply change creates excess demand for $\mathrm{N}$ and thus gives extra real appreciation.

Consequently, this generates further labour changes from $\mathrm{L}$ into $\mathrm{N}$, strengthening the deindustrialization caused by the outcome of expenditure. The next result is known as indirect deindustrialization.

In addition, Odior (2014) investigated the effects of the exchange rate on non-oil exportations in Nigeria from 1986 to 2013 with the help of the OLS technique. Odior (2014) recognized that the essential factors of agricultural GDP include a real monetary total and infrastructural change, while the meaningless impact on Nigeria's agricultural GDP was agricultural loans and government expenditure. In contrast, non-oil exports have a substantial impact on exchange rates, the supply of money, private-sector credit, and real GDP while the appreciation of the exchange rate has a negative outcome on Nigeria's non-oil export. Brownson (2003), using co-integration and error correction (ECM) examined the effect of macroeconomic variable indecision on agricultural productivity in Nigeria. He demonstrated the significant long-term and short-term harmful effects that real exportations, actual external reserves, inflation, and external debt have on agriculture productivity, whereas the use of agricultural volumes and nominal exchange rates promote agricultural output in Nigeria.

\section{Agricultural Promotion Policy in Nigeria}

Initially in 2010-2011, after years of neglect, the Nigerian government began restructuring the agricultural sector. A new strategy called the Agricultural Transformation Agenda (ATA) was used by the government to re-focus the sector on the concept that agriculture has to be a business and that it should thus be supported by the ATA policy. The ATA's main objective was to restore sustainable agriculture to a Nigerian economy that focuses on business-like private sector attitudes. The policy was in place from 2011 till 2015 (Adeniji, 2013).

The ATA was a good avenue for re-engaging substantial stakeholders in Nigerian agriculture to concentrate on how to build an economy that was consumed by self-sustaining agribusiness. The ATA centred on how to make the agricultural production of Nigeria more industrious, skilled and effective. It set the goal of establishing 3.5 million jobs by 2015 ; creating foreign exchange and lowering food import expenditure. A reform of the federal fertilizer procurement system was one of its key achievements. 
However, ATA also faced problems and failed to achieve all the established goals. Nigeria, for example, still imports food worth around $\$ 3$ to $\$ 5$ billion annually, particularly wheat, rice, fish and assorted items, which include fresh fruit. As a consequence, Nigeria is not secure for food. Waste levels remain high in manufacturing areas, reducing the supply of raw material to processing factories, requiring them to maintain supply imports. The net effect is insufficient employment growth across the agricultural value chain from input development to market systems, and constant use of limited foreign currency earnings to import large amounts of food.

The ATA was a major step towards resurrecting agriculture on equilibrium. Many businesses, persons and influencers are now being encouraged as a product to invest again in Nigerian agriculture. Agriculture can be seen as a business that can provide a legitimate basis for Nigeria's continued capital and employment growth.

In this light, Nigeria is now becoming a new level of agri-business reliability in policy and strategic concentration on building on the subsequent progress. This will be the focus of the present political regime. This new policy focuses primarily on closing demand-supply gaps between livestock production and manufacturing. Closing the gap will contain issues related to inputs, funding, storing, transportation and access to the market in major value chains (Adeniji, 2013).

\section{Problems Faced by the Agricultural Sector in Nigeria}

Chuba (2015) explained some problems faced by the agricultural sector in Nigeria as follows:

1. Lack of Development: Development shortages in particular are a problem with Nigeria's agriculture. The lack of improvement includes social development (advancement related to its people and country), economic development (expansion related to the country's finances and wealth), and environmental development (growth-related to air quality, water, soil, etc.) and political development (growth related to the political system). Categorizing and addressing development limitations in the agricultural system in Nigeria will help create an atmosphere for performance improvement and help foster and speed up growth in this sector (Chuba, 2015).

2. Marketing problem: Marketing entails the transmission to consumers of agricultural products from farmers. Several of the marketing issues that affect the agricultural sector in Nigeria include poor means of transport, poor packaging and low quality. If you do have a weak packaging structure (making products look nice and desirable to customers) and your rival has a stronger packaging model than what you do, then buyers are more likely to purchase from your rival even if the qualities are of the same (Chuba, 2015). Better roads are required to move goods efficiently from one area to another. Sadly, the country's general marketing scheme is primitive. It takes many years sometimes up to a decade for federal agencies that have been assigned to build roads and railways for transportation to get a network built due to corruption. Due to inadequate maintenance, even the small road and rail built usually collapse.

3. Storage and processing: The absence of storage and processing infrastructures influences both food safety at the national level and food safety at home. Even when there is a ton of harvest and farm product production seems sufficient, it would still result in food shortages due to lack of good storage as the food may not be accessible or in good shape when it becomes time for intake. Strong storage and processing are necessary to maintain that food is available in excellent condition whenever necessary. Simple and efficient methods for storing perishable foods such as tubers, fruits and vegetables are still not developed and are not well known in 
Nigeria especially in comparison to grains (Chuba, 2015). Because of the lack of storage and processing facilities, storage is a problem for Nigeria as a large number of food products perish. The conventional storage techniques used emit flaws, such as low level, which thus is easily accessible to the rodent and has a wooden floor that is an attractive target for termite, and even some of the storage are non-moisture-proof surfaces that could cause water damage because of the insufficient storage and processing structure, farmers lose heavily, particularly when it's time to harvest abundantly. Safe areas to store products are inefficient and insufficient. Experts from distinct institutes established an improved storage system and technique, but these structures were not adopted and often not even known by farmers.

4. Lack of good Infrastructure: In this case, infrastructure includes structures such as equipment for health and education, welfare services (sustainable electric power and safe drinking water) and a good communications network. Nigeria's agriculture is suffering badly from the absence of developed infrastructure. In the rural area, for example, where most ranchers perform without decent infrastructure, a key issue is that it affects investment, trade, and agricultural development. This issue is mostly created by the government, as the government supports urban growth by a huge margin over rural development. Because of bad political administration, bad governance, government abandonment, the poor culture of maintenance and poor financing, the lack of infrastructure continues (Chuba, 2015). Electricity, clean water and health equipment are often insufficient for those living in rural areas, as the government favours the urban environment more. For instance, people living in rural areas could be daily without electrical power for up to a week, and even the urban area has no reliable electricity. Most locations in the villages have a water tap that doesn't always work due to the lack of electrical power, so water used throughout the farm and houses is bought from the rivers, which may take hours to pick up as the river might be far from the houses and farms.

\section{Structure of Agricultural Output in Nigeria}

The various sub-sectors which are form are namely crop production, livestock, forestry, and fishing (CBN, 2018). It can be considered that the crop sector of the economy takes the massive portion of agricultural yield over the entire period, preceded by the subsector of livestock production. Sub-sectors of both forestry and fisheries have similar shares for the same period. In 1984, crop production had its lowest share of $76.37 \%$ and its highest share of $90.16 \%$ in 2012. By distinction, in 2012, livestock production had a low share of $6.79 \%$ and a peak share of $17.35 \%$ in 1984. In addition, forestry input was highest in 1984 (3.3\%) and lowest in 2016 (1.03\%). Finally, fisheries' largest contribution was set at 1.41 per cent in 1994 and its largest input was set at 4.07 per cent in 1983. According to CBN (2018), crop harvesting regulated farming actions in the fourth quarter of 2016. Farming operations in the southern part of the country centred on tubers, fruits and vegetable harvesting, while farmers in the northern part were engaged in early grain harvesting and pre-planting procedures in dry season plan. Farmers involved in the stuffing of cattle and broilers in the livestock and fisheries sub-sectors, respectively, are desperate to sell at the end of the year. The crop sub-sectors main input can be attributed to the sector's huge share in the allocation of loans from the Agricultural Credit Guarantee Scheme (ACGS), preceded by sub-sectors for livestock and fisheries.

\section{Inflation Rates}

Changes in currency exchange rates are caused by inflationary variations. Moreover, currency appreciation will be seen in a country with a moderately lower inflation rate. The price of goods 
and services increases at a rapid rate when inflation is lower. Countries with an ongoing stubborn inflation rate demonstrate an increasing currency rate, whereas countries with increasing inflation commonly experience depreciation of the currency and higher interest rates.

\section{Interest Rates}

Interest rates, inflation and exchange rates are interrelated. Central banks can influence inflation and exchange rates by affecting interest rates. Higher interest rates provide a greater yield to creditors than other countries some interest rate increase allows the country's monetary value to rise, as higher interest rates lead to higher rates for borrowers, thereby generating more foreign capital, leading to higher exchange rates.

\section{Theoretical Framework}

Monetary Policy Transmission Mechanism: This theory as explained by Berg (2002) stated that variables like the interest rate and the exchange rate can drive output growth if the policy environment is accommodative for growth to occur. An accommodative period would be a period of low-interest rate which allows manufacturers to borrow for purpose of production and consumers for purpose of consumption thus reducing the financial constraint for both economic agents. A weak exchange rate can boost export demand which leads to expansion in agricultural yield. Output tends to respond to interest rate and exchange rate changes in the short run.

\section{Empirical Framework}

According to the studies of Udensi, Orebiyi, Ohajianya, \& Eze (2012), there existed a negative connection between real exchange rates and demand-side agricultural exports. Also, Studies by Antonia (2008) and Adeniran, Yusuf, \& Adeyemi (2014) also found a negative relationship between real exchange rates and non-oil exports (including agricultural exports) for Nigeria.

In another study conducted by Ajobo \& Oguntade (1996), Akpan (2015), and Olomola (1994), it was further explained that unforeseen domestic currency appreciation increased supply-side agricultural output, although it depends on the combined effect of demand and supply elasticity. But the weak bargaining power of primary goods in developing countries, therefore, outweighs the elasticity of supply that of foreign demand.

According to Ibeabuchi, S. N. (2007), agricultural credit increases productivity and promotes living standards by breaking the vicious cycle of farmers' poverty. Ijaiya \& Abdulraheem (2000), Obadan \& Nosa (2009), and Devereux, Lane, \& Xu (2006) as quoted in Ibeabuchi (2007) stated that timely and easy access to agricultural credit allows farmers to purchase the input and machinery required to carry out farms operations and increase production. In order to maintain the same level of income, agricultural producers (mostly peasant farmers) must produce more as the currency depreciates. Awoke (2004), Anietie (2004), Campa \& Goldberg (2005), and Adeniji (2013) detailed that export price is a function of agricultural exports.

Export prices, therefore, have a positive relationship with agricultural exports. According to Taylor \& Taylor (2004), the higher the price of U.S. exports compared to foreign exports, the smaller the demand for U.S. agricultural exports would be. Yue \& Jahjah (2004) adopted an 
amended IS-LM framework to investigate the impact of the exchange rate on the output of various sectors (agricultural and services).

Oriavwote \& Oyovwi (2012) used the Vector Error Correction Model (VECM) to examine the link between the deregulation of exchange rates and Nigeria's agricultural share of GDP and found a long-run relationship. Chichi \& Camir (2014) used a two-stage least square method to analyze the effect on aggregate exports of the real exchange rate and found a significant effect between both variables.

Husain, A.M, Mody, A., \& Rogoff, K. S. (2005) used the Auto-regression Distributed Lag (ARDL) model to investigate the effect of the volatility of exchange rates on selected agricultural exports in Iran and found the exchange rate to be highly volatile.

Finally, a study carried out by Chuba (2015) estimated the impact of exchange rate fluctuations on Nigerian agricultural exports. From the above review, it is evident that there is no dominant approach to studies on the impact of exchange rate fluctuations on agricultural exports. Choosing a specific approach or methodology and expected outcomes depends on a specific economy and nature, study objective, and data availability.

\section{Gaps in Literature}

The study used the works of Bobai, Ubangida, \& Umar (2013) in constructing its model specification but their work omitted the monetary policy transmission mechanism. The monetary policy transmission mechanism explained that monetary policies are the major drivers of sectoral growth in any economy.

Also, there is a year gap as the study used data from 1986 - 2019 while most of the reviewed literature used data from 1980 to 2016 which makes this work more current and reliable.

\section{Model Specification}

The model used in the study was adopted and modified from the study of Bobai, Ubangida, \& Umar (2013) and its implicit form is:

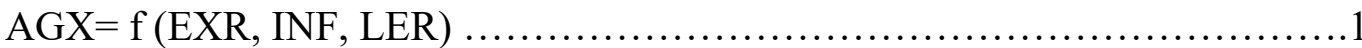

The explicit econometric model is expressed as:

$\mathrm{AGX}_{\mathrm{t}}=\beta 0+\beta 1 \mathrm{EXR}_{\mathrm{t}-\mathrm{i}}+\beta 2 \mathrm{INF}_{\mathrm{t}-\mathrm{i}}+\beta 3 \mathrm{LER}_{\mathrm{t}-\mathrm{i}}+\mu(2)$

Where

AGX $=$ Agricultural export

$\mathrm{EXR}=$ Exchange rate

$\mathrm{INF}=$ Inflation rate

$\mathrm{LER}=$ Interest rate

$\mu=$ Stochastic Disturbance

(Error term) 
British Journal of Management and Marketing Studies

ISSN: 2689-5072

Volume 4, Issue 4, 2021 (pp. 9-20)

$\beta_{0}=$ intercept of relationship in the model/ constant

$\beta_{1}-\beta_{3}=$ coefficient of each of the independent variable

By log linearizing the model becomes

$\log (A G X)_{t}=\beta 0+E R_{t-i}+I N F L t-i+\operatorname{LER}_{t-i}+\mu$

The study used secondary data from 1981 - 2020 culled from the Central Bank of Nigeria statistical bulletin (2020). The data collected for the study would be analyzed using inferential statistics. It would be used to show the correlation between the exchange rate and agricultural export. It will make use of the T-test statistics to tell the stated hypothesis. It would also be making use of ordinary least square (OLS) it seeks to closely fit a time series data, it reduces the sum of squared errors from the data to the barest minimum and also a method of estimating the unknown parameter is using linear regression

\section{DATA PRESENTATION, ESTIMATION AND ANALYSIS}

\section{Augmented Dickey-Fully (Unit Root Test)}

The Augmented Dickey fuller which is also called the Unit Root test was used for testing the data which resulted in the use of the ordinary least square method (Gujarati \& Porter, 2004). It is expected that Augmented Dickey fuller test statistics should be greater than $10 \%$ test critical values; it is by this that the variables are declared stationary or non-stationary. Hence, the table below shows that all the variables were stationary at levels and trend and intercept;

Table 4.1: Unit Root Table (Augmented Dickey-Fuller @ Levels, Trends and Intercept)

\begin{tabular}{|l|l|l|l|l|}
\hline Variable & $\begin{array}{l}\text { ADF } \\
\text { Test statistics }\end{array}$ & $\begin{array}{l}10 \% \text { test critical } \\
\text { Values }\end{array}$ & Stationarity & Remarks \\
\hline EXR & -7.329475 & -2.548120 & Stationary at levels & $\mathrm{I}(0)$ \\
\hline INF & -3.484312 & -2.548120 & Stationary at levels & $\mathrm{I}(0)$ \\
\hline LER & -5.631579 & -2.548120 & Stationary at levels & $\mathrm{I}(0)$ \\
\hline LAGX & -4.701505 & -4.320498 & Stationary at levels & $\mathrm{I}(0)$ \\
\hline
\end{tabular}

\section{Analysis of the Ordinary Least Square Method}

From the table below in 4.2

R-squared was 0.64 (64\%) which implied that all the independent variables explain $64 \%$ of the dependent variable. After adjusting for the degree of freedom the R-square was adjusted to $0.59(59 \%)$.

Durbin Watson test is used for Auto-correlation; this means that all the variables are not correlated. It is expected that Durbin Watson must be equal to 2 or approximately 2 to prove that there is no autocorrelation among the variables. The table below shows the Durbin Watson test to be 1.94 . 
British Journal of Management and Marketing Studies

ISSN: 2689-5072

Volume 4, Issue 4, 2021 (pp. 9-20)

www.abjournals.org

The Probability value from the result must be at a $10 \%$ significance level to show that it is significant in explaining the dependent variable.

From the probabilities given in the regression,

- The probability value for the Exchange rate (EXR) was 0.0356 which showed that is statistically significant at $10 \%$.

- The probability value for inflation rate (INF) is 0.0251 , meaning that it is also statistically significant at $10 \%$

- The probability value for interest rate (LER) is 0.6831 which is statistically insignificant at $10 \%$

To examine the sign of the relationship, the sign of the coefficient was examined. From the coefficient given in the regression,

- The coefficient of the exchange rate (EXR) was 0.651687 which has a positive sign and showed that it is positively significant.

- The coefficient of inflation rate (INF) was -0.097533 and carried a negative sign which proved its negative significance.

- The coefficient of interest rate (LER) was 0.003429 which carried a positive sign and thus makes the variable positively insignificant

Table 4.2: Ordinary Least Square (OLS) Table

\begin{tabular}{|l|l|l|l|l|}
\hline Variables & Coefficient & Standard error & t-statistics & Probability \\
\hline LER & 0.003429 & 0.017164 & 0.199795 & 0.6831 \\
\hline INF & -0.097533 & 0.074604 & -1.307345 & 0.0251 \\
\hline EXR & 0.651687 & 0.295082 & 2.208493 & 0.0356 \\
\hline C & -0.959366 & 2.017509 & -0.475520 & 0.8340 \\
\hline $\begin{array}{l}\text { R-Squared } \\
R^{2}=0.64\end{array}$ & $\begin{array}{l}\text { Adjusted R- } \\
\text { Squared } \mathrm{R}^{2}=0.59\end{array}$ & $\begin{array}{l}\text { Durbin-Watson }= \\
1.94\end{array}$ & & \\
\hline
\end{tabular}

\section{DISCUSSION OF RESULT}

From the result of the regression, the exchange rate was statistically significant at $10 \%$ which explained that the exchange rate as a macroeconomic variable has a significant effect on the agricultural sector as it affects the exportation of agricultural products to other nations.

Also, from the result of the analysis, the coefficient of inflation rate was negatively significant in the agricultural sector development. This explains that the increase in prices of commodity and affect export of agricultural. 


\section{RECOMMENDATIONS}

These recommendations are because of the result gotten from the estimation technique:

1. The monetary authorities should make policies that would reduce inflation, for example, the reduction of the money supply. Reduced inflation would positively impact the development of the agricultural sector as it would boost and increase the consumption of agricultural products.

2. Policies to reduce imports and boost export should be made by the government. Policies like the devaluation of the naira would reduce imports but it must simultaneously work with the increase in export and this would boost the agricultural sector.

3. More policies should be put in place for the agricultural sector in Nigeria in other to develop more strategies that can make agricultural business in Nigeria booming and also attract foreign investors.

\section{REFERENCES}

Adeniji, A. (2013). Investigating relationship between currency substitution, exchange rate and inflation in Nigeria, Ekiti: MPRA publishers

Adeniran, J. O.Yusuf, S.A. \& Adeyemi, O. A. (2014). The impact of exchange rate fluctuation on the Nigerian economic growth: An empirical investigation. International Journal of Academic Research in Business and Social sciences, 4(8), 224 - 236.

Ajobo, O. \& Oguntade, A.E. (1996). Does an Agricultural Financial Institution Pay Attention to Organic Economic Development? A Case-Study, Journal of Financial Management and Analysis, 9(2), 52-58.

Akpan, O. (2015). Exchange rate volatility and inflation rate in Nigeria, Harvard University Press, Harvard.

Anietie, H. (2004). The Real Exchange Rate and Economic Growth, Harvard University Press, Harvard

Antonia, M.O. (2008). The Dynamics of Exchange Rate in Nigeria, MIT Press, Cambridge Anyawu, J.C. (1997). The Structure of the Nigeria Economy (1960-1997), Joanne Onitsha, Nigeria, Educational Publishers Ltd

Awoke, M. U. (2004). Factors affecting Loan Acquisition and Repayment Patterns of Smallholder Farmer in Ika North- East of Delta State, Nigeria, Journal of Sustainable Tropical Agriculture Research, 9(3), 61-64.

Berg, U. (2002). Exchange Rate and Economic Growth, Harvard University Press, Cambridge.

Bleaney, F. \& Fielding, D. (1999). Exchange Rate and Inflation, PRS publishers, Washington.

Bobai, A., Ubangida, I. \& Umar, A. (2013). Exchange rate and volatility and inflation, Kano: MPRA publishers.

Brownson, W (2005). Effect of exchange rate on Agricultural growth in Nigeria. Journal of Business and Economics, 10(3), 10-24

Campa, J. M. \& Goldberg, L. S. (2005). Exchange rate pass-through into import prices, Review of Economics and Statistics, 87(4), 679-690.

Central Bank of Nigeria (2018). Annual Report and Statement of Account, Lagos: CBN. 
Central Bank of Nigeria (2019). Annual Report \& Statement of Account, Lagos: CBN.

Chichi, O. A \& Camir, K. (2014). Exchange rate and the economic growth in Nigeria, International journal of management sciences, 2(2), 78-87.

Chuba, M. A. (2015). Exchange Rate Pass-through in Nigeria, Economics, 4(3), 41-49.

Devereux, M. B., Lane, P. R., \& Xu, J. (2006). Exchange rates and monetary policy in emerging market economies. The economic journal, 116(511), 478-506

Frankel, J. A. (2003). Experience of and lessons from exchange rate regime in emerging economies (No. w10032). National Bureau of Economic Research.

Gujarati, D. N., \& Porter, D. C. (2004). Basic econometrics (ed.). New York, McGraw-Hill

Husain, A.M, Mody, A., \& Rogoff, K. S. (2005). Exchange rate regime durability and performance in developing versus advanced economies. Journal of monetary economics, 52(1), 35-64.

Ibeabuchi, S. N. (2007). Overview of monetary policy in Nigeria, $C B N$ Economic and Financial Review, 45(4), 15-37

Ijaiya, G. T. \& Abdulraheem, A. (2000). Commercial banks credits to the agricultural sector and poverty reduction in Nigeria: A calibration analysis. Nigerian Journal of Agriculture Business and Rural Development, 1(1), 143-157.

Inam, U. S., \& Oscar, W. A. (2017). Exchange Rate Volatility and Non-Oil Imports in Nigeria: A Co-integration Analysis. Advances in Social Sciences Research Journal, $4(16), 12-26$

Mordi, N. O. (2006). Challenges of exchange rate volatility in economic management in Nigeria, Journal of Economics and Finance, 6(3), 17-25.

Obadan, M. I. \& Nosa, E. (2009). Exchange rate regimes for developing and emerging markets, Central Bank of Nigeria Bullion, 60(5), 12-29

Odion, E. S. (2013).Macroeconomic variables and the productivity of the manufacturing sector in Nigeria: A static analysis approach. Journal of Emerging Issues in Economics, Finance and Banking, 1(5), 362-380.

Odior, E. S. (2013).Macroeconomic variables and the productivity of the manufacturing sector in Nigeria: A static analysis approach. Journal of Emerging Issues in Economics, Finance and Banking, 1(5), 362-380.

Olomola, A. S. (1994). Changes in rural and agricultural credit policies in the structural adjustment in Nigeria, Quarterly journal of international agriculture, 1(3), 18 - 27

Oriavwote, V. E., \& Oyovwi, D. O. (2012). The determinants of the real exchange rate in Nigeria. International Journal of Economics and Finance, 4(8), 150-160.

Sial, M. H., \& Carter, M. R. (1996). Financial market efficiency in an agrarian economy: Micro-econometric analysis of the Pakistani Punjab. The Journal of Development Studies, 32(5), 771-798.

Taylor, A. M., \& Taylor, M. P. (2004). The purchasing power parity debate, Journal of economic perspectives, 18(4), 135-158

Udah, S. C., Nwachukwu, I. N., Nwosu, A. C., Mbanasor, J. A., \& Akpan, S. B. (2015). Determinants of Agricultural Export Growth in Nigerian. International Journal of Agriculture, Forestry and Fisheries, 3(3), 105.

Udensi, A. I., Orebiyi, J. S., Ohajianya, D. O., \& Eze, C. C. (2012). Determinants of macroeconomic variables that affect agricultural production in Nigeria. International Journal of Agricultural and Rural Development, 15(3), 1169-1173.

Yue, V. Z., \& Jahjah, M. S. (2004). Exchange rate policy and sovereign bond spreads in developing countries, International Monetary Fund Paper No. 4210 